\title{
礫・シルト充填河床モデルを用いた 植生を伴う流路の変動解析 \\ NUMERICAL ANALYSIS OF CHANNEL DEFORMATION \\ ON THE BASIS OF GRAVEL-SILT MIXTURE MODEL IN RIVER BED
}

\author{
関根正人 1 ・矢島英明 2 \\ Masato SEKINE and Hideaki YAJIMA \\ 1 正会員 工博 早稲田大学教授 理工学部社会環境工学科（T 169-8555 東京都新宿区大久保 3-4-1) \\ 2 正会員 工修 建設技術研究所（ $\bar{T} 103-8430$ 東京都中央区日本橋本町 4-9-11, 当時, 早稲田大学大学院学生)
}

\begin{abstract}
The channel deformation of gravel-bed river with vegetation zone was investigated in the present study. The channel is assumed to be constituted by a gravel-silt mixture. In order to simulate such a phenomenon, the erosion rate of silt from gravel bed surface is the important factor to be considered. The formulation by Ashida and Fujita (1986) was applied here in the numerical model. Numerical computation was conducted by considering the effect of silt erosion and deposition on the channel deformation. As a result of this, it was confirmed that the depositional configuration like a terrace formed just inside the vegetation zone, which was mentioned by Fujita et al. (1996).
\end{abstract}

Key Words: gravel bed river, gravel-silt packed model, vegetation, numerical analysis, washload.

\section{1. 序論}

著者らは, 近年, 鬼怒川 $54.5 \sim 56.5 \mathrm{~km}$ の区間を 対象として洪水前後に引き起こされた流路変動につ いて現地調查を含めた研究を進めてきている.この ような河川の礫床区間における流路変動の特徴の一 つとして, 低水路を構成する主要材料である礫に比 べてはるかに粒径の小さな微細砂あるいはシルト が, 河岸水際付近あるいは高水敷に堆積すること が挙げられる. 藤田ら ${ }^{1)}$ は, 川内川や米国 Powder Riverにおける調查ならびにデータの解析結果を裏 付けとして，(1) 水際付近へのシルトの堆積，（2） 堆積部分への植生の繁茂, （3）植生帯への更なるシ ルトの堆積によるテラス状の地形の形成, の結果と して高水敷が形成されることを指摘し，これが実際 に生じた低水路川幅の縮小の原因になったと論じて いる.このような磁とシルト（あるいは微細砂）か らなる顕著な粒径差をもつ材料の移動床過程を考え ていく上では, 磁間からのシルトの巻き上げ量の評 価法や，この巻き上げが引き起こされる混合粒径河 床の取り扱い方などをより合理的で精緻なものへと
変えていくことが重要である。これまでの河床変動 計算を概括すると，たとえば板倉・岸 ${ }^{2)}$ の式など 主として砂床河川を想定して導かれた巻き上げ速度 式が適用されることが多いが，この関係式を砂間に 存在するシルトなどの浮上・巻き上げに適用できる か否かは定かではない，また，混合粒径河床の変動 を予測する場合には，一般に，交換層の概念に依拠 した取り扱いがなされてきたが，上記のシルトの巻 き上げの取り扱いと河床のそれとは当然密接に関わ りをもつため, 両者の間で整合性のとれた解析法を とることが望ましい，以上の点に鑑み, 本研究では, 芦田・藤田 ${ }^{3)}$ が実験結果を基に導いたシルトの巻 き上げ速度式を適用することにし，この考え方を生 かした混合河床モデルを考案した。

\section{2. 碟・シルト充填河床モデルと解析の概要}

\section{(1) 概要}

本研究では，これまで必ずしも的確に取り扱うこ とのできなかった「砂・シルト混合材料」からなる 河道の流路変動過程について解析した. 詳細は後述 
することにして，解析手法の骨子を列挙すると，以 下のようになる．才なわち，（i ）浅水流方程式に 依拠した平面二次元流れの解析 ${ }^{4)}$ ，（ii）縦横断方 向の勾配の影響を考慮して拡張化された掃流砂量関 数を用いた䃇の輸送量の評価, （iii）シルトの河床 からの巻き上げ予測式 ${ }^{3)}$ と, 水深平均化された移 流拡散方程式に基づくシルトの輸送に関する解析, (iv ) 斜面崩落モデル5) による河岸浸食の取り扱い, ならびに $(\mathrm{v})$ 後述する礫とシルトからなる二粒径 混合河床を取り扱う「礫・シルト充填河床モデル」 を用いた河道の変動予測計算, などからなる.

浮遊した土砂の浱度に関しては, 上記の通り水深 平均化された移流拡散方程式を解くことで評価する ことにしたが，この際には底面近傍濃度 $C_{b}$ を評価 することが必要となる．ここでは，濃度の鉛直方向 分布として Lane-Kal inske 型の指数分布に従うもの として, 水深平均蕽度と $C_{b}$ とを関連づけて解いて いる. また, 濃度拡散係数については, 従来通り水 の乱流拡散係数に等しいものと近似した.

本研究で検討の対象とする現象としては, 序論で 説明したような「植生群落内へのシルトの堆積とそ れに伴うテラス状の地形の形成過程」である.

\section{（2）䂺河床からのシルトの巻き上げ速度}

いま，河床の主たる骨格が砂により構成され，そ の間隙をシルトが埋めているような礫床河道につい て考える. シルトは, 水流の作用を受けて浮遊形式 の移動をするため, その河床からの動き出しは, 一 般に「浮上」あるいは「巻き上げ」と表現される. なお, シルトのその後の移動が浮遊砂であるのかウ オッシュロードであるのかはここでは問題とせず, 従来の考え方に倣って土砂の移流 - 分散過程として 取り扱うことにする. さて, シルトの河床からの巻 き上げ量の評価についてはこれまでにいくつかの研 究がなされている.しかし，ここで想定しているよ うな礫床からの土砂の巻き上げ量の予測に適用でき る予測式はほとんどなく, わずかに芦田・藤田 ${ }^{3)}$ の式があるだけである，そこで，本研究では，この 関係を用いることにする。この予測式の詳細につい ては原論文の説明を参炤することが望ましく、ここ では論文構成上必要な知見, すなわち基本的な考え 方と導かれた巻き上げ速度式そのものについてのみ 簡単に説明しておく.

芦田・藤田 ${ }^{3)}$ は, 図-1に示すような礫とシルト (あるいは細砂）からなる河床について実験的な検 討と, 確率論的手法に基づく理論的な取り扱いから, シルトの巻き上げ速度式を導いている．彼らによれ ば, 粒径 $D_{G}$ の砂骨格の頂部に相当する河床表面の

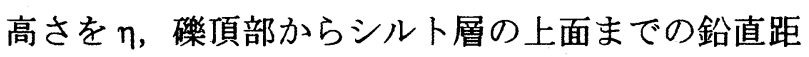
離を $\Delta s$ とする. そして, 最も重要なことは, 粒径

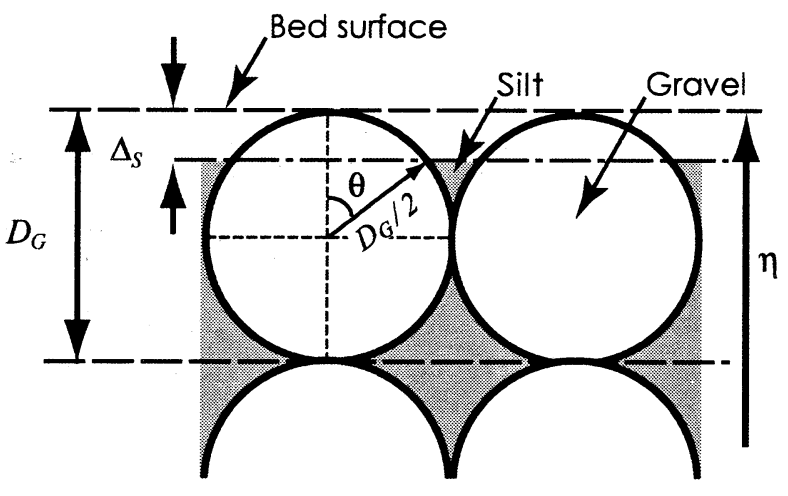

图 -1 礫 -シルト混合河床に関わる定義

$D_{S}$ のシルトの巻き上げ量は，その上の水流の掃流 力に加えてこの $\Delta s$ の影響を顕著に受けるというこ とにある。これは，シルトの浮上に砂による遮蔽効 果が無視し得ないためである. 芦田・藤田により導 かれた巻き上げ速度式を整理し直すと，次のように 書き表わされる.

$$
E_{s}=\frac{2}{3} K F_{s} \sqrt{\frac{3}{R_{s}+1}} \frac{1}{\pi} \frac{\sqrt{c k^{2}}}{\xi_{o}} \int_{\chi_{o}}^{\infty} \sqrt{\chi^{2}-\chi_{o}^{2}} e^{-\frac{\chi^{2}}{2}} d \chi
$$

$$
\xi_{o}=\frac{w_{o}}{u_{\star}}, \chi_{o}=\frac{\pi}{8} C_{D \circ} \frac{\xi_{o}^{2}}{c k^{2}}, C_{D_{o}}=2+\frac{24}{\frac{w_{o} D_{s}}{\nu}}
$$

ここに， $E_{S}$ は単位時間・単位面積当たりに巻き上げ られるシルトの体積をその最終沈降速度 $w_{0}$ で除し た無次元量を表す. また, 式中の $c$ は揚圧力係数, $k$ は遮蔽係数であり, 前者は $R_{e}^{*}=u_{*} \Delta_{s} / v$ の関数と なり, また, 後者は $\Delta s / D_{G}$ の関数となることがそ れぞれ示されている．そこで，この関数を考慮する ことで， $E_{S}$ の評価が可能となる．なお， $R_{S}$ はシル 卜の水中比重, $v$ は水の動粘性係数, $C_{D o}$ は抗力係 数であり, $K$ は定数 $(=0.035)$ である.

\section{（3）䂺・シルト充填河床モデル}

礫とシルトからなる混合河床の変動を予測する上 では, この芦田・藤田の巻き上げ速度式を適用する のがその信頼性において最良の選択であることはす でに述べた。そこで、ここではこれを組み込んだ河 床変動解析法について考えることにする. 従来の河 床変動計算では，一般に「交換層」という概念を導 入して「河床面高さ」と「碴とシルトの混合比率」 の時空間的な変化を評価する，その際，交換層の厚 さを $90 \%$ 粒径の数倍程度にとるなどして，この層 内で碎とシルトが均一に混合されるとしてきた。し かし, 芦田・藤田の予測式を実際に適用しようとす ると，式 (1) 中に現れる $c$ および $k$ を支配する物理 量である「碟間を埋めるシルトの上面の高さ」 $\Delta s$ を 同時に評価しつつ変動計算を進めていくことが必要 


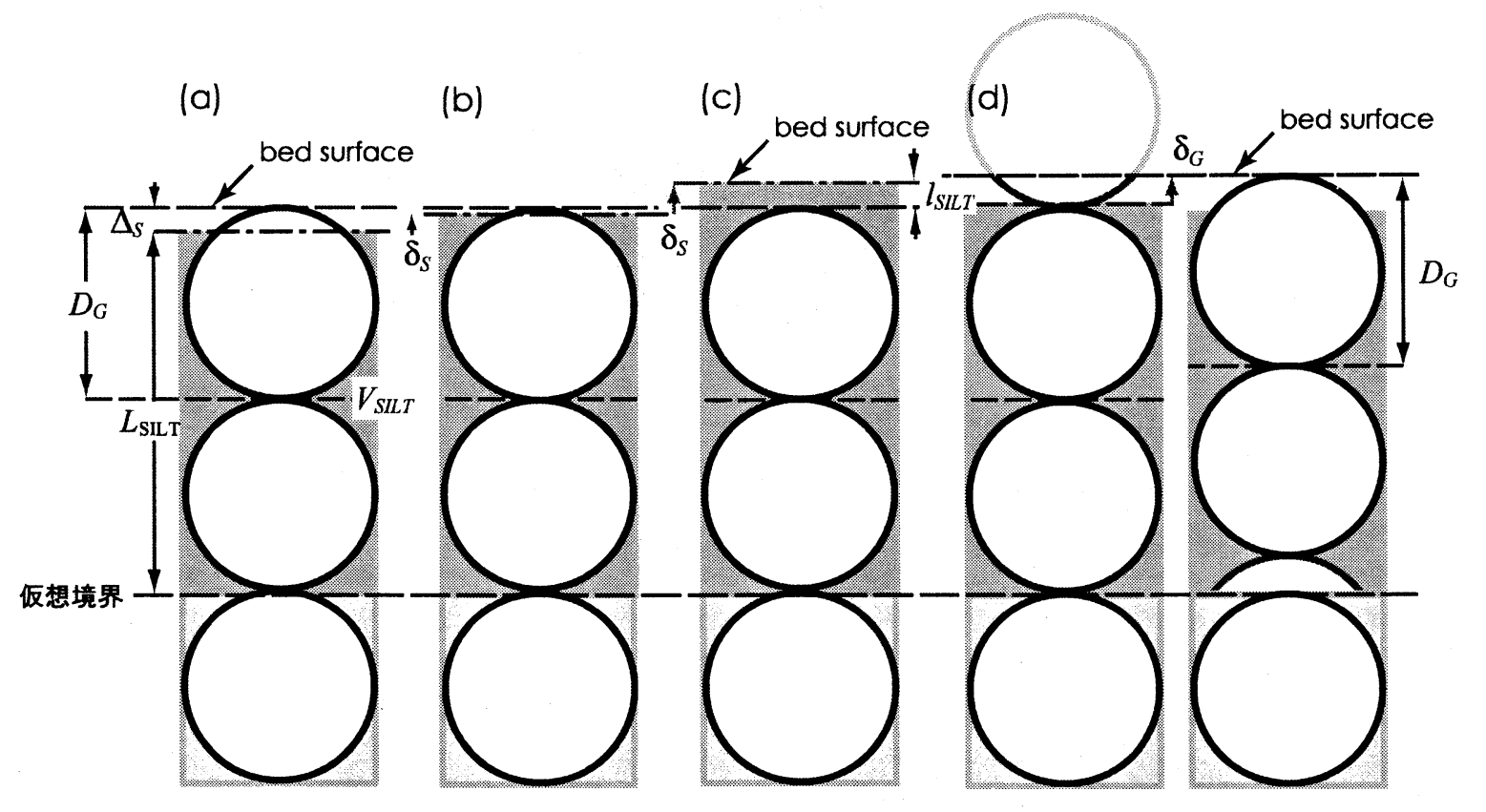

図 -2 磷 -シルト混合河床における変動の概念図 : 図の着色部にシルトが充填されている.

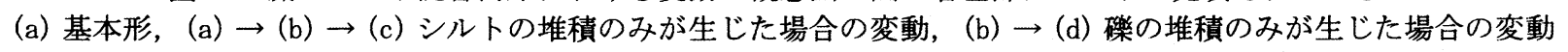

となる.このような取り扱いを可能とするため, 本 研究では, 以下に説明するような河床の取り扱い方 法を考案した. 以下，これを「碟・シルト充填河床 モデル (Grave1-Silt packed model)」と呼ぶ.

ここでの基本的な考え方は, (a) 河床は原則とし て礫群によりその骨格が形作られる，(b) シルトは 磁骨格の間隙を充填するように存在するが，間隙を 充填して余りある量のシルトがある場合には, 礫頂 部を越えてシルトだけの堆積層が形成される，とい うものである. さらに，芦田・藤田よれば，礫間か らのシルトの巻き上げは, $\Delta s$ が礫径 $D_{G}$ 以上になる と生じないとされるため, ここでは碩径に相当する 厚さの表層（言い換えれば, コントロール・ボリュー ム）を河床表面下にとって，土砂の混合を考えてい く，そこで, 粒径 $D_{G}$ を一辺とする立方体をコント ロール・ボリュームにとって説明していくことにす る.この中に含有される礫の体積は $\pi D_{G}^{3} / 6$ であり, $D_{G}{ }^{3}$ のボリュームのうちシルトによって充填される 体積は, 砂以外で占められる体積から水で満たされ る空隙部分を差し引いたものということになる. そ こで, 敢えてこの空隙を $\lambda_{p}$ と記すと,このコントロー ル・ボリューム内に含有されるシルト体積の上限值 V packed は,

$$
V_{S \text { packed }}=\left(1-\lambda_{p}\right)(1-\pi / 6) D_{G}^{3}
$$

となる. また, このコントロール・ボリューム内に 存在するシルトの含有率 $F_{s}$ は,

$$
F_{S \text { packed }}=\frac{\left(1-\lambda_{p}\right)(1-\pi / 6)}{\pi / 6+\left(1-\lambda_{p}\right)(1-\pi / 6)}
$$

となる.このように礫骨格の間隙がシルトで充填さ れた状態を full-packed condition と呼ぶことにする. 次に, 同一のコントロール・ボリュームにおいて, 碟頂部から $\Delta s$ の高さまでしかシルトが充填されて いない場合について考えると，図-1より,ここに 含まれるシルトの体積 $\mathrm{V}_{s}$ は,

$\frac{V_{S}}{D_{G}^{3}}=\left(1-\lambda_{p}\right)\left[1-\zeta-(\pi / 12)\left(1+\cos \theta+\frac{1}{2} \cos \theta \sin ^{2} \theta\right)\right]$

となる.ここに, $\zeta=\Delta_{S} / D_{G}, \cos \theta=1-2 \zeta$ ある. またこのコントロール・ボリューム内のシルトの 混合比率 $F_{s}$ は次のように書き表される.

$$
F_{S}=\frac{V_{S}}{\pi D_{G}^{3} / 6+V_{S}}
$$

そこで, コントロール・ボリューム内のシルト体積 $\mathrm{V}_{s}$ を求めることができれば，この式から $F_{s}$ を求め ることができる。一方， $V_{S}$ が既知であれば，式 (4)の 関係をらについて解くことで $\Delta s$ を求めることができ る.このように, 河床表層のコントロール・ボリュー ム内に存在するシルトの体積に関する保存則から $V_{S}$ の值の時間変化を追跡していくことにより, 河床面 下のシルトに関する情報がすべて得られることにな る.

図 -2には，河床上昇が生じる場合を例に変動パ ターンの模式図を示した。これを用いて河床の取 


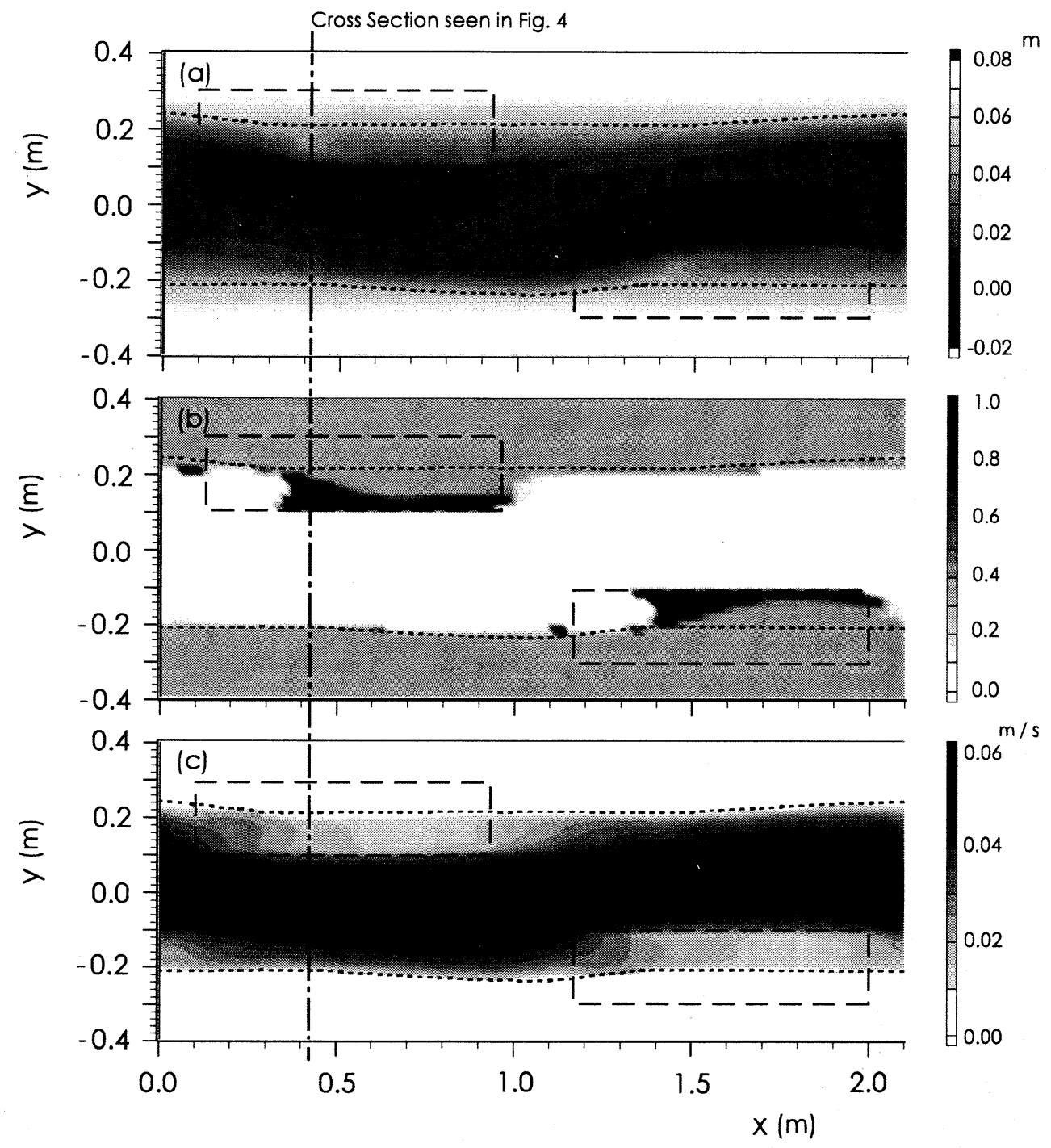

図 -3 数值解析結果：（a）水路床高等值線図，（b）表層におけるシルトの含有率，（c）摩擦速度の等值線図 図中の破線で囲まれた部分が植生群落区域を，点線が水際線をそれぞれ表す，一点鎖線は，図 -4 の横断面位置を表す。

り扱いの概要について説明する。ここでは，前述の 通り, 最も上位に位置する碟の頂部を河床表面と し，これ以下に位置する礫は互いに接するように密 に配置されているものと近似する。図-2 の場合に は，便宜上，第二層目の磁の底部を仮想境界にとり， これより上に存在する碟およびシルトの体積保存則 を考えていく。まず，図－2(a) から (b) を経て (c)へ と到る過程は, シルトのみの堆積が生じる場合を表 す。この場合には，䃇骨格の配置に変化が生じない ため，堆積するシルト体積に見合った厚さだけシル 卜面が上昇する。この図 -2(a) から (b) の過程では, 碑骨格の間隙に更なるシルトの充填が行われるだけ であるので, 河床面高さは変わらない, しかし, 図 -2(b) から (c) の過程においては, 磁上部に新たにシ ルトの堆積層が形成されるため, このシルト層の上 縁が新たな河床面ということになる．この過程の解
析では，まず最初に碟群の間隙中の未充填部分の体 積を求め,この過程で生じた総堆積量からこの量を 差し引いた体積 $\Delta V_{s}$ を評価する．次にこの体積に見 合ったシルトの堆積層が生じるものとして, その 厚さ $l_{S L T}$ を $\left(\Delta V_{S} / \mathrm{D}_{\mathrm{G}}{ }^{2}\right) /\left(1-\lambda_{\mathrm{p}}\right)$ により求める. 一方, 図 -2 (b) から直接 (d) へと変化する過程は, 碟のみ が堆積する場合を表している．図 -2(d) 左側には礫 の上面が $\delta_{\mathrm{G}}$ だけ上昇する場合の模式図が示されて いる，図のように礫間がシルトで充填されていない 河床に対して芦田・藤田の巻き上げ速度式を適用し ようとすると, 砂頂が河床表面と一致するような磎 配列となるように置き換えて河床を捉えることが 必要となる。そこで，ここでは，図 -2(d) 右側に示 したように，碟ならびにシルトの体積がそれぞれ等 価な配列をもつ河床に置き換えて, シルトの巻き上 げを考える。 この場合には，仮想境界より上方に 
あるシルトの体積が変わらないためシルト上面の位 置も不変である，いま，仮にこのあとも砂のみの堆 積が続くとすると, やがてはシルトの充填が一切な されていない础表層が生み出されることになる．前 述の通り, $\Delta s / D_{G}$ が 1 を越えるとシルトの巻き上げ は生じないため, さらにこの変化が続いたとしても, これ以降のシルトの巻き上げは生じないため, もし 新たにシルトの堆積が生じるまではシルト面高さの 変化は止まることになる.

以上，説明を簡単にするために砶あるいはシルト の堆積が単独で生じる場合の考え方を示したが，両 者が同時に堆積を起こす場合や，これとは逆に浸食 が生じる場合についても基本的には同一の考え方に 基づいてこれを取り扱うものとする.

最後に, 砂頂部の高さならびにシルト体積の時間 変化量について説明する，まず，礫に関しては，そ の存在比率を考慮しつつ体積保存の関係式に基づい て計算し, 河床骨格をなす磁頂部の高さを求める. 一方, 仮想境界面上に存在するシルト体積に関して は, 次の体積保存の関係から評価する。ここでは, $D_{G} \times D_{G}$ の大きさの底面上の直方体を想定し，この中 に含まれるシルト体積をVSILT としてある.

$$
\frac{d V_{S I L T}}{d t}=D_{G}^{2} w_{o}\left(C_{b}-E_{s}\right)
$$

次に, この体積 $V_{S L T}$ から表層のコントロール・ボ リューム内のシルト体積 $V_{S}$ を求める. その際, シル トで充填済みの碩層がある場合には，式 (2) を考慮 することになる．そして，この $V_{S}$ の值を式 (4) に代 入し，これをらについて解くことで，シルトの上面 の高さを評価することができる.

ここでは，礫径 $D_{G}$ に一致する大きさのコントロー ル・ボリュームをとって説明してきたが，実際には $\Delta x \mathrm{x} \Delta y$ の大きさをもつ計算格子に対してこの取り扱 いを行うことになる．また，この「礫・シルト充填 河床モデル」は， $\Delta s$ を合理的に評価することを主た る目的として導入されることになるが，これ以外の 礫の移動やシルトの巻き上げあるいは堆積の量につ いてまで従来と異なる取り扱いをしたわけではない. この点に注意が必要である．また，幾何学的に理想 的とも言えるこのような状態を仮定することの影響 についても検討の余地がある.これについては今後 の課題である. ただし，このような考え方によれば, ここでは触れなかった三粒径以上の混合砂砂に対し ても拡張して取り扱うことが比較的容易である.

\section{3. シルトの堆積に伴うテラス地形の形成}

本研究では, 礫床河川の流路変動に及ぼすシルト
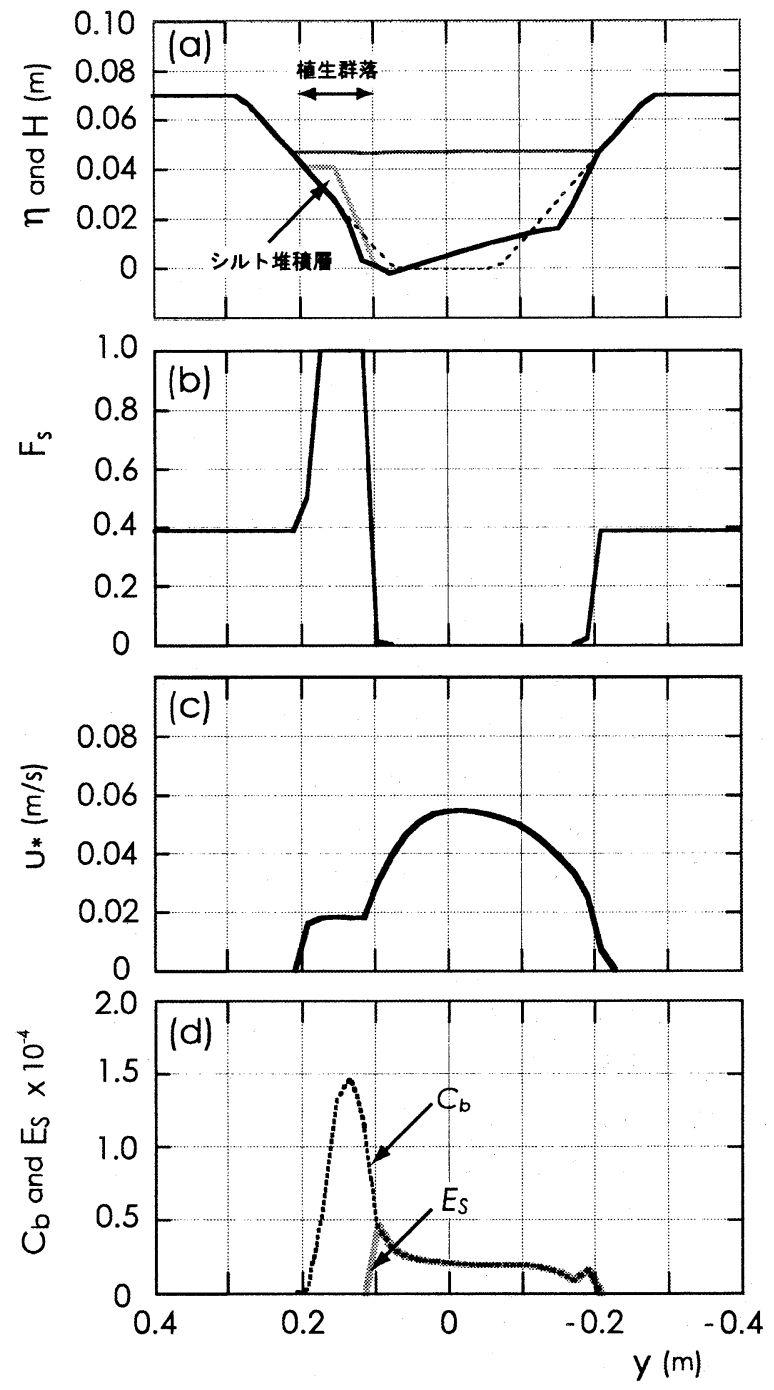

図 -4 注目断面における諸畺の横断方向分布 :

（a）横断面形状（破線が初期河床），（b）表層におけるシル トの含有率（初期值は 0.389），(c) 摩擦速度, ならびに (d) 無次元巻き上げ速度と浮遊砂の底面近傍濃度

の堆積の影響について考える．具体的には，シルト の堆積が植生によって促進されるとの指摘があるこ とを考慮して，著者らがこれまで進めてきた解析 ${ }^{4)}$ の延長線上に本解析を展開する，すなわち，初期 状態として, 底面幅 $14 \mathrm{~cm}$, 横断方向勾配 $1 / 3$, Bank の高さ $7 \mathrm{~cm}$ の台形断面を有する移動床直線流路の 水際付近に, 植生群落が左右交互に存在するような 場を想定する．初期水路床は，その骨格を粒径 2.5 $\mathrm{mm}$ の砂で形成し，その間隙を $0.1 \mathrm{~mm}$ のシルトが充 填しているものとする. 解析に当たっての水理条件 ならびに植生条件は，前報によるもの ${ }^{4)}$ と同一で あり，たとえば，流量を $5.16 \mathrm{l} / \mathrm{s}$ ，平均水路床勾配 を 0.008 , 植生密度を 1.25 とする.解析に当たっては, 植生群落が周期的に複数組存在するものとし，上下 流端で周期境界条件を適用することで, 植生群落に 
見合ったいわば平衡状態の解を求める.

ここでの主な解析結果を図 -3 および図 -4 にまと めて示した. なお, この解析結果はほぼ動的平衡状 態におけるものと言える. まず，図 -3 には，通水 開始から 90 分後の水路床高, 表層におけるシルト の含有率ならびに摩擦速度の等值線図ををまとめて 示した。 まず，図-3(a) の水路床高に関しては，植 生群落の流路中心軸側の境界面に沿うようにその外 側に洗掘域が形成される。この点は前報 ${ }^{4)}$ で議論 した鿬のみの場合と変わらない。一方, 図-3(b) に 示した表層に占めるシルトの含有率について見る と, 植生帯の端に沿ってその内側にシルトの比率が 高い区域があることがわかる．特に図中に一点鎖線 を付した横断面の周辺では, かなり内側にまで黒で 塗り分けられた区域，すなわち表層がシルトで 100 \%占められている区域が及んでいることがわかる. これは，この区域にシルトが層をなして堆積したこ とを表す。この一方で, 流路中心部には白で塗り分 けられた区域，すなわち表層がほとんど磁のみに なっている区域が現れている。これは，この部分の シルトが表層から巻き上げられたことを意味し，全 体として䫓著な土砂の分級が生じていることがわか る. 図-3(c) には流れ場に関わる情報として, 参考 までに摩擦速度の分布を示してある.この図より， シルトの堆積域では結果として摩擦速度が大きく低 下していることが見て取れる.

図-4には，図-3に一点鎖線を付して示した横断 面における諸物理量の分布をまとめてある。まず, 図 -4(a) より,この断面の左岸側にシルトがテラス 状に堆積していることがわかる. また，図-4(b) よ りこの堆積域の表面がシルトのみで構成されている こと，ならびに，その右側の流路中央部では逆にシ ルトが存在していないこと, などが理解できる. 最 後に, 図 $-4(\mathrm{c})(\mathrm{d})$ より, この断面の植生帯内では, 浮遊土砂を運び込むことはあってもこれを再浮上さ せるほどの掃流力がないことが見て取れる．なお， テラス状の地形が植生帯の下流側で顕著に成長しな いのは, 植生の前面を通して運び込まれたシルトの 堆積がその上流側に限られ, 下流側の土砂濃度の供 給が側面を通しての拡散によるものだけとなるため と判断している.

このように, 植生によってシルトが捕捉され, 結 果としてテラス状の地形が形成されることが数值解 析によっても理解された. 序論で紹介した低水路川
幅が縮小する現象は，ここでの解析対象と同様のメ カニズムによって引き起こされるのではないかと考 える.

\section{4. 結論}

本研究では, 磉床河川における流路変動の予測を 合理的に取り扱うための手法について検討した。こ こでは, 礫の間隙からのシルト（細砂）の巻き上げ 量を予測する手法として最も信頼性の高い芦田・藤 田の予測式を適用することにした，そのため，この 予測式の考え方と整合性のとれた解析手法となるよ うに「砂・シルト充填河床モデル」と名づけた河床 表層の取り扱い方を導入した. 本研究では, この解 析手法を用いて，植生帯内に堆積したシルトが新た にテラス状の地形を形成する過程を再現することに 努め, 概ねその目的を達することができたと考える. しかし，未だ十分な検討とは言えず，今後に残され た課題は少なくない. 更なる研究を進めていく予定 である.

謝辞 : 本研究は, 河川懇談会共同研究 (関東地方整備局 下館河川事務所）の一環として，また国土交通省建設技 術研究開発助成「環境ホルモンの無害化と暴露量削減に 関する研究開発」の一部として行われたものである.

\section{参考文献}

1）藤田光一, John A. Moody, 宇多高明, 藤井政人: ウオッ シュロードの堆積による高水敷の形成と川幅縮小，土木 学会論文集, No.551/II-37, 47-62, 1996.

2) Itakura, T. and Kishi, T. : Open channel flow with suspended sediments, Proc. ASCE, Vol. 106, HY8, 1325-1343, 1980.

3）芦田和男, 藤田正治: 平衡・非平衡浮遊砂量算定の 確率モデル，土木学会論文集，No.375/II-6, 107-115, 1986.

4）関根正人 - 矢島英明 : 植生群落を伴う河道の流路変動 予測に関する研究, 水工学論文集, 第 48 巻, 1045-1050, 2004.

5）関根正人：斜面崩落モデルを用いた網状流路の形成過 程シミュレーション, 水工学論文集, 第 47 巻, 637-642, 2003.

（2004.9. 30 受付） 